\section{INFLUENCE OF SNOBBERY ON THE PRACTICE OF MEDICINE}

$\mathrm{T}$

HE lecture entitled "The Hand in Healing: a Study in Greek Medicine from Hippocrates to Ramazzini", delivered before the Royal Institution on December 4 by Prof. B. Farrington, professor of classics at University College, Swansea, has now been published by the Institution. In it Prof. Farrington discusses three topics: (1) the decline of anatomy and surgery after Galen; (2) the limitation of ancient medicine to the rich and the professional classes; (3) the invasion of medical science by a priori philosophical concepts. His object is to show that the decline in social status of the manual labourer (a) prevented the development of physics and chemistry, and $(b)$ caused a gradual deterioration of anatomy and surgery. That chemistry and physics, in the modern sense, were practically unknown, that surgery after Galen was separated from medicine and rapidly declined, are admitted truths; the novelty in Farrington's paper is his finding the cause of these phenomena in the Greek dislike of what were called "banausic" occupations. This is a most ingenious suggestion, almost certainly containing an element of truth. The evidence, however, should be closely examined before the hypothesis is accepted; in a few places Prof. Farrington appears to have misunderstood it.

The meaning of "banausic occupations" raises a thorny question. "Banausia" seems to have been an Athenian conception, appreciated perhaps throughout Greece but to a less degree than at Athens. It signifies not so much a prejudice against manual work in itself-for full honour was given to painters, sculptors, soldiers and farmers-but only against wearying trades involving long hours in conditions that ruin the worker's physique and dull his intellect. Moderns feel a similar prejudice against certain monotonous operations in factories. Such pursuits are harmful ; we are learning that "banausic" work should be done by machines rather than by men and women. The dislike of the Greeks was the result of a healthy instinct, but they are to be blamed because while accepting the facts they relegated "banausic" labour so far as possible to slaves, in order to have the leisure to live full lives as citizens. The first man to interest himself in occupational disease was apparently Paracelsus, who wrote a treatise on the ailments of miners. Be all this as it may, it would be difficult to show that medicine or even surgery was ever ranked among the "banausic" arts ; by the time surgery came to be despised, the Greek ideals that gave rise to "banausia" had ceased to exist.

On p. 15 Prof. Farrington states that "the Hippocratic medicine was already (fifth century B.c.) limited in its application to a section of the people", that is, to the idle rich. Yet medical historians such as Rossignol (in 1858), Littré and Couch (in 1934) have pointed out that the patients of the Hippocratic clinical histories are for the most part humble folk, being indeed often slaves. This fact has to be reconciled with Plato's statement that for slaves there were slave doctors.

Prof. Farrington also takes the view that the long treatise "Regimen" was a medical text-book written by a typical Hippocratic physician for general use. This is extremely doubtful. It was probably the work of a professional trainer, who with a special purpose wrote for a special public-those who, fearing lest their work should be interrupted by a threatened illness, wished to 'nip it in the bud'. To call such people valetudinarians (p. 17) is perhaps unfair.

The intrusion of speculative philosophy into medicine, vigorously attacked by the author of "Ancient Medicine", appears, if we may judge from the subsequent literature, never to have had much effect on actual medical practice. Every art, in addition to the practical theory that explains and reinforces it, has beyond this a speculative background of theory pure and simple. This speculation has a useful part to play, the classic example being Manson's guess that mosquitoes are connected with malaria, a guess that led to the discoveries of Ross. In the infancy of science it tended to encroach upon practical theory, so that the author of "Ancient Medicine" felt bound to protest. Greek thought, in fact, was over-rich in this intelligent guesswork, throwing out suggestion after suggestion in wild profusion. We moderns on the other hand are prone to undervalue it, although every now and then a Jeans or an Eddington inspires us with restrained and beautiful speculation. On the whole, however, we confine such thought to fiction. We should not like to read $\mathrm{H}$. G. Wells's fascinating theories in a textbook.

On p. 28 of Prof. Farrington's lecture we read: "almost two thousand years after Aristotle . . . was explicitly formulated ... the belief in the existence of definite bodies capable of being isolated . . . and recombined into new compounds". The latter half of this sentence would surely be a good description of the atomistic hypothesis of Democritus !

Even if these criticisms be justified, Prof. Farrington's lecture is of great value, and must certainly be taken into account by historians of Greek thought. W. H. S. Jones.

\section{THE GAS RESEARCH BOARD}

$\mathrm{T}$

HE Gas Research Board, which is supported by the Institution of Gas Engineers, the Society of British Gas Industries, and other bodies and individuals in the British gas industry, has recently issued its second report*. War-time conditions have prevented publication of some of the research done under its auspices and also the holding of the normal autumn research meeting.

The thirty-second report of the Refractory Materials Joint Committee*, which is also published, records, among other subjects, experiments on the materials used in the manufacture of firebacks for open coke fire-grates. Reference is made to the advantages in heating efficiency and performance of the use of the insulating refractory firebricks which have been so extensively developed in recent years.

Two reports, issued by the Gas Research Fellows for the year 1939-40 and 1941, deal with properties of Bunsen flames-in particular with flame ignition and propagation. There are two methods of measuring flame velocity: (a) the static method whereby propagation through a stationary explosive mixture is measured photographically; and $(b)$ when the velocity is calculated from the form and size of the stationary inner cone of a Bunsen flame and the known rate of gas mixture fed to the burner. Hitherto results have shown great discordance, which has

* (1) Communication G.R.B. No. 4. Pp. 16. (2) Communication G.R.B. No. 5. Pp. 92. (London: Gas Research Board, 1941.) 
now been traced to the unjustified assumption that the inner 'cone' of a Bunsen flame is a true cone. It has now been shown that if the true area of the inner cone is measured and used in the calculation, then ignition velocities are obtained by this method which are independent of rate of mixture feed and burner size, depending only on working temperature and pressure. In other words, the ignition velocity so determined is a characteristic of the composition of the gas-air mixture. This should greatly facilitate the study of flame combustion.

It is often overlooked that the inner cone of a Bunsen flame does not touch the burner, from which it is separated by a 'gap' or 'dead space' in which the mixture is preheated to the temperature at which inflammation occurs. It appears that the size of the 'dead space' determines the possibility of 'lighting back', for when the diameter of the burner is reduced to twice the 'dead space', then the flame cannot pass down the tube. The influence of size of tube and hole in stopping the travel of flame is well known and usually ascribed to the cooling, but it now appears to be essentially a characteristic of the gas.

\section{FORTHCOMING EVENTS}

\section{(Meetings marked with an asterisk are oxen to the public)}

\section{Tuesday, May 12}

CHADWIOK PUBuTC LECTURE (at the Royal Society of Tropical Medicine and Hygiene, 26 Portland Place, London, W.1), at 2.30 p.m.

Illuminating ENGineming Societr (at the Institution of Mechanical Engineers, Storey's Gate, St. James's Park, London, S.W.1) at 5.30 p.m.-Mr. G. H. Wilson : "Street Lighting: Past, Present and Future".

\section{Wednesday, May 13}

ROYal Societr of ARTs (at John Adam Street, Adelphi, London, W.C.2), at 1.45 p.m.-Miss Helen Masters: "The Post-War Home", 11: "Domestic Offices, Equipment and Maintenance".

Pharmacedtical Societry of Great Britarn (in the Small Hall of Friends House, Euston Road, London, N.W.1), at 2.30 p.m.-Dr. Philip Hamill : "Prescribing in War-time."

InstindTe of METals (at the Institution of Mechanical Engineers, Storey's Gate, St. James's Park, London, S.W.1), at 6 p.m.-Mr. the Production of Metals" (Thirty-second Annual May Lecture).

\section{Friday, May 15}

ROYAI INSTITUTION OF GREAT BRITAIN (at 21 Albemarle Street, London, W.1), at 5.15 p.m.-Prof. H. C. Plummer, F.R.S.: "Galileo and the Springtime of

\section{Sunday, May 17}

Association of Scientific Workers (Southern ARfa) (in the Refectory, University College, Southampton, at $2.30 \mathrm{p} . \mathrm{m}$. Conference on "Science for Victory" *

\section{APPOINTMENTS VACANT}

AppLICATIONs are invited for the following appointments on or before the dates mentioned:

DEPUTY BOROUGH EleCTRIOAL ENGINEER in the Electricity Undertaking of the Woolwich Metropolitan Borough Council-The Town Clerk, Town Hall, Woolwich, London, S.E.18 (May 15).

Principal of the Walker Techicical Colrege, OAKengatesThe Secretary for Education, County Buildings, Shrewsbury (May 16). CIVIL ENGINEERING AssistanT-The Clerk to the River Ouse

(Yorks) Catchment Board, 7 Iangcliffe Avenue, Harrogate (May 20).

INSPECTOR OF AGRICDLTURE to serve during his early years as Lecturer in the School of Agriculture near Khartoumham Gate, London, S.W.1 (endorsed "Inspector of Agriculture") (May 25).

UNIVERSITY ChaIR OF RADIOLOGY (THERAPEUTIC) tenable at Middlesex Hospital Medical School-The Academic Registrar, University of London, Richmond College, Richmond, Surrey (May 26).

HeAD OF THE ChemistRY DepartMent-The Secretary, Robert

Gordon's Technical College, Aberdeen (May 30).

LeCTURER IN BIOLOGY (PART-TIME)--The Principal, Bishop Otter College, Chichester.

LECTURER (WOMAN) IN BIOLOGY AND HoRTruderure-The Principal, The Training College, Lincoln.

LFCTURER IN GROGRAPHY (PART-TIME) at the Brighton Municipal Training College-The Education Officer, 54 Old Steine, Brighton.

Assistant (MALE) to the Public Analyst-The Secretary, Health Department, Grey Friars, Leicester.

\section{REPORTS and other PUBLICATIONS}

\author{
(not included in the monthly Books Supplement)
}

\section{Great Britain and Ireland}

British Rubber Producers' Research Association. Publication No. 15: The Molecular Weights of Rubber and related Materials, 3 : A Correction of Part 2; 4: The Micellar Theory of the Structure of Rubber. By G. Gee.' Pp. 8. (London: British Rubber Producers' Researeh Association.)

\section{Other Countries}

U.S. Department of the Interior: Geological Survey, Bulletin 890-B : Spirit Leveling in South Carolina, Part 2: Southern South Carolina, 1896-1938. Pp. ii +457-766+plates 1-2. 40 cents. Bulletin 900-D : Subsurface Geology and Oil and Gas Resources of Osage County, Oklahoma, Part 4: Townships 24 and 25 North, Ranges 10 and 11 East. By L. E. Kennedy, J. D. McClure, H. D. Jenkins an N.W. Bass. Pp. iv $+131-172+$ plate 4.35 cents. Bulletin 900-E Oklahoma, Part 5: Townships 26 and 27 North, Ranges 10 and 11 East. By L. E. Kennedy, W. E. Shamblin, Otto Leatherock and N. W. Bast. Py L. iv +173-208 + plate 5. 40 cents. Bulletin 901 : Clay In. vestigations in the South States, 1934-35. Reports by W. B. Lang Vestigations in the South States, 1934-35. Reports by W. B. Lang, Munyan. Pp. $x+346+8$ plates. 1 dollar. Bulletin $907:$ Geology of the Munyan, Pp. $x+346+8$ plates. 1 dollar. Bulletin 907 : Geology of the
Alaska Railroad Region. By Stephen R. Capps. Pp. vi $+202+9$ plates. 1.25 dollars. Bulletin 913: Triangulation in Utah, 1871-1934 plates. 1.25 dollars. Bulletin 913 : Triangulation in Utah, 1871-1934.
$\mathrm{Pp}$. iv $+170+1$ plate. 20 cents. Bulletin 914: Microscopic DeterPp. iv $+170+1$ plate. 20 cents. Bulletin $914:$ Microscopic Deter-
mination of the Ore Minerals. By M. N. Short. Second edition. Pp. viil $+314+14$ plates. 1 dollar. Bulletin $915-A$ : Geophysical Abstracts 10, January-March 1939. Compiled by W. Ayvazoglou. Pp. ii +48 . 1939. Compiled by W. Ayvazoglou. Pp. if +49-86. 10 cents. Bulletin 915-C : Geophysical Abstracts 98, July-September 1939. Compiled by W. Ayvazoglou. Pp. ii + 87-132. 10 cents. Bulletin 916-D : Transit Traverse in Missouri, Part 4: Northwestern Missouri, 1911-37. Pp. $\mathrm{Xx}+441-564+1$ plate. 20 cents. Bulletin 916-E : Transit Traverse in Missouri, Part 5 : Southwestern Missouri, 1900-37. Pp. xiv +565-732+ 1 plate. 25 cents. Bulletin 916-F : Transit Traverse in Missouri, Part 6 : Northeastern Missouri, 1900-37. Pp. xiii + 733-868 +1 plate, Central Missouri, 1902-37. Pp. xiv $+869-1024+1$ plate, 25 cents Bulletin 922-A: Quicksilver Deposits of the Bottle Creek District, Humboldt County, Nevada. A Preliminary Report by Ralph J. Roberts. (Strategic Minerals Investigations, 1940.) Pp. iii $+29+$ plates 1-5. 35 cents. Bulletin 922-B: Quicksilver Deposits of the Mount Diablo District, Contra Costa County, California. By Clyde $P$. Ross. (Strategic Minerals Investigations, 1940.) Pp. iii $+31-54+$ plates 6-8. 10 cents. Bulletin 922-C: Manganese Deposits in the Little Florida Mountains, Luna County, New Mexico. A Preliminary Report by S. G. Lasky. (Strategic Minerals Investigations, 1940.) Pp. iii + 55-74 + plates 9-11. 25 cents. Bulletin 922-D : Chromite Deposits of Grant County, Oregon. A Preliminary Report by T. P. plates 12-20. 45 cents. Bulletin 922plates A Preliminary Report by R. J. Roberts. (Strategic Minerals Investigations, 1940.) Pp. iii +115-134+ plates 21-23. 15 cents. Bulletin 922-F : Tungsten Deposits of Boulder County, Colorado. By T. $\mathrm{S}$. Lovering. (Strategic Minerals Investigations, 1940.) Pp. iii $+135-156+$ plates 24-25. 20 cents. Bulletin 922-G Manganese Deposits at Philipsburg, Granite County, Montana. A Preliminary Report by iv $+157-204+$ plates $26-34.40$ cents. Bulletin $422-1940$.) Pp. iv $+157-204$ + plates 26-34. 40 cents. Bulletin 922-H: Tungsten Deposits of the Atolia District, San Bernardino and Kern Counties, California. By Dwight M. Lemmon and John V. N. Dorr, 2d. (Strategie Minerals Investigations, 1940.) Pp. iv +205-246+plates 35-37. 25 cents. Bulletin 922-I : Antimony Deposits of a part of the Yellow Pine District, Valley County, Idaho. A Preliminary Report by Dii +247-280+ plates 38-39. 30 cents. Bulletin 922-K : Antimony Deposits of the Wildrose Canyon Area, Inyo County, California. By Donald E. White. (Strategic Minerals Investigations, 1940.) Pp. iii $+307-326$ + plates $45-46$. 25 cents. Bulletin 922-M : Tin Deposits of the Black Range, Catron and Sierra Counties, New Mexico. A Proliminary Report by Carl Fries, Jr. (Strategic Minerals Investigations, 1940.) Pp. iii $+355-370$ +plates 54-62. 50 cents. (Washington, D.C.;
Government Printing Office.) [144
U.S. Department of Agriculture. Farmers' Bulletin No. 1893: Control of Grape Diseases and Insects in Eastern United States. B J. B. Demaree and G. A. Runner. Pp. ii +28. (Washington, D.C. Government Printing Office.) 10 cents.

Publications of the Dominion Observatory, Ottawa. Vol. 13 Bibliography of Seismology, No. 10: Items 5135-5279, July to December 1941. By Ernest A. Hodgson. Pp. 157-188. (Ottawa [20]

Transactions of the San Diego Society of Natural History. Vol. 9, No. 32 : A Vertebrate Faunal Survey of the Organ Pipe Cactu National Monument, Arizona. By Laurence M. Huey. Pp. 353-376. Vol. 9, No. 33 : Notes on some Mexican and Californian Birds, with Descriptions of Six Undescribed Races. By A. J. van Rossum. Pp.
$377-384 . \quad$ (San Diego, Calif.: 377-384.) (San Diego, Calif.: San Diego Society of Natura
History.)

The South African Journal of Science. Vol. 38: Being the Report of the Thirty-ninth Annual Meeting of the South African Association for the Advancement of Science, Johannesburg, 1941, 30th June and 1st July. Pp. xx +399. (Johannesburg: South African Association for the Advancement of Science.) 308. net.

Department of Science and Agriculture, Jamaica. Report for the Year ending 31.st March 1941. Pp. 6. (Kingston: Government
Printing Office.) 